\title{
Erratum to: HIZ's relation to axial load and low back pain: investigated with axial loaded MRI and pressure controlled discography
}

\author{
Hanna Hebelka • Tommy Hansson
}

Published online: 21 November 2012

(C) Springer-Verlag Berlin Heidelberg 2012

\section{Erratum to: Eur Spine J}

DOI 10.1007/s00586-012-2501-y

In the affiliations the authors' first names and family names have been changed.

The correct names are H. Hebelka and T. Hansson.

The online version of the original article can be found under doi:10.1007/s00586-012-2501-y.

H. Hebelka

Department of Radiology, Sahlgrenska University Hospital,

Gothenburg, Sweden

H. Hebelka ( $\square)$

Barnröntgen, Drottning Silvias Barn och Ungdomssjukhus,

Smörslottsgatan 1, 41685 Gothenburg, Sweden

e-mail: hanna.hebelka@vgregion.se

T. Hansson

Department of Orthopaedics, Sahlgrenska University Hospital,

Gothenburg, Sweden 